\title{
Monitoring of Turbidity Variation in the Ukai Reservoir, Gujarat, INDIA, during 1993-2018 using Landsat Series of Dataset
}

\section{Pompapathi ${ }^{* 1}$, Shard Chander ${ }^{2}$, Ashwin Gujrati ${ }^{3}$, H.A. Solanki ${ }^{4}$, R. P. Singh ${ }^{5}$}

"Land Hydrology Division, GHCAG/EPSA,Space Applications Centre, ISRO, Ahmedabad, India

Department of Environmental Science, Gujarat University, Ahmedabad, India

${ }^{2}$ Land Hydrology Division, GHCAG/EPSA, Space Applications Centre, ISRO, Ahmedabad, India

${ }^{3}$ Land Hydrology Division, GHCAG/EPSA, Space Applications Centre, ISRO, Ahmedabad, India

${ }^{4}$ Department of Environmental Science, Gujarat University, Ahmedabad, India

${ }^{5}$ Land Hydrology Division, GHCAG/EPSA, Space Applications Centre, ISRO, Ahmedabad, India

\section{Article Info}

Volume 8, Issue 6

Page Number : 236-251

Publication Issue

November-December-2021

\section{Article History}

Accepted : 15 Nov 2021

Published : 22 Nov 2021

\section{ABSTRACT}

Turbidity is one of the important water quality parameters, which is required to understand the eco-hydrological process such as a trophic state of water, soil erosion into the river system, mixing of other water sources, runoff, discharge etc. An algorithm has been developed to estimate the turbidity (in NTU: Nephelometric Turbidity Unit) over inland waters using Red band of optical multispectral dataset. Field measurements were carried out over Ukai reservoir for 27-28 ${ }^{\text {th }}$ March 2018 for pre monsoon and 27-30 ${ }^{\text {th }}$ September 2018 for post monsoon seasons, sampling sites ranging from turbid to clear water. Where in situ water leaving reflectance and turbidity were measured. Model was derived between in situ measured turbidity and spectral reflectance of Red band of Landsat series of datasets includes Landsat 5 Thematic Mapper (TM), Landsat 7 Enhanced Thematic Mapper Plus (ETM+) and Landsat 8 Operational Land Imager (OLI) data from 1993-2018. The model was applied to derive the turbidity maps of Ukai reservoir for pre-monsoon (March, April and May months) season and post monsoon (September, October and November months) seasons. Overall turbidity was in the range of 1.47-25 NTU during the field data collection for both pre and post monsoon seasons. To investigate the results in detail, the reservoir was divided into three parts, i.e. Down (A), Middle (B) and Up Streams (C). The water was relatively clear in the downstream portion with average turbidity less than 5 NTU over the study period. While maximum turbidity was observed in the upstream portion with values more than 20 NTU. In the middle portion, the turbidity values were fluctuating within the range 4-13 NTU with an average value of 6 NTU. These turbidity maps can be used to determine underwater light attenuation that has importance in ecosystem modelling.

Keywords : Turbidity, Ukai Reservoir, Relative Spectral Response (RSR), Landsat satellite. 


\section{INTRODUCTION}

Turbidity is one of the most important water quality parameters and a surrogate for water clarity [12]. Total suspended sediment (TSS) concentration is an important water quality indicator of turbidity, riverine flus, bank erosion and current or wind generated resuspension [13]. An increase or decrease of water clarity may lead to impact on biological components of the system that may be adapted to specific light penetrating conditions [10].Total suspended matter (TSM) is an important water quality parameter and plays a key role in water quality evaluation, especially of inland waters (e.g. lake, reservoir and river). TSM determines the transparency of water and ultimately determines the primary productivity of water [34]. Sediment transport from large rivers plays an important part in geological, biological and chemical processes on the earth surface [5]. Lake waters are characterized by suspended organic and inorganic materials. Suspended materials serve as a carrier and storage agent of pesticides, absorbed phosphorus, nitrogen and organic compounds and can be an indicator of pollution. Therefore, it is very important to monitor and assess the concentrations of suspended materials in lake waters, as well as their spatial and temporal distribution and change [36].

Inland water variables such as suspended matter and phytoplankton are spatially heterogeneous parameters, corresponding synoptic information cannot be obtained from in-situ monitoring networks. TSM is traditionally measured by collecting water samples and analyzing them in the laboratory. Monitoring TSM in this way can be time consuming and require a large amount of human and material resources if a large area is involved. Furthermore, a limited number of field samples often cannot truly characterize the spatial variation of TSM within a body of water. This problem, however, can be solved by the integration of water quality models, in-situ data and remote sensing data that provides spatially distributed information [7].Nowadays satellite remote sensing has been widely used to monitor inland water quality. With the development of remote sensing technology, remote sensing data have been utilized to assess TSM [7] [25] [15]. Estimating TSM with remote sensing has four main advantages, ability to cover large areas, rapid results, low costs and convenience for dynamic monitoring [26]. The combination of temporal coverage, spatial resolution and data availability makes the Landsat system particularly useful for assessment of inland lakes [16]. The extra benefit of using remote sensing for water quality analysis is its ability to capture synoptic data of a whole region of interest to produce continuous surface data and spatial variability in water quality [1]. Landsat 8 Operational Land Imager (OLI) and Thermal Infrared Sensor (TIRS) has been widely used in coastal management and has been demonstrated to be a useful tool for monitoring of coastal sediment concentrations at high resolution and accuracy due to its higher signal to noise ratio $(\mathrm{S} / \mathrm{N})$ compared to previous Landsat images [30]. Besides, Landsat 8 has been involved with 12 bits of radiance resolution compared to 8 bit for the older ones, Landsat 5 Thematic mapper (TM) and Landsat 7 Enhanced thematic mapper plus (ETM+).

Turbidity values generally correlates with reflectance at satellite bands located in the red part of the spectrum for low to moderate turbidity values. Landsat band 3 (630-690 nm) has been used to map turbidity in Guadalquivir River (Spain) for a turbidity range 1.5 - 8 NTU [3]. A good correlation 
between LISS-I red band (620-680 nm) and turbidity in the range of 15-45 NTU in the Tawa reservoir in India [6] [11]. Goodin et al., 1996 used SPOT-HRV2 red band (610-680 $\mathrm{nm})$ to map relatively low levels of turbidity, ranging from 3 to 15 NTU, in the Tuttel Creek reservoir in Kansas, USA. [24]. developed a regional algorithm for MODIS-Aqua $250 \mathrm{~m}$ red band to map turbidity in the Adour river plume (Bay of Biacay, France), where field turbidity values varied between 0.5 and 70 NTU. A multiple linear regression analysis using Landsat red band (630-690 nm) and near infrared (750-900 nm) bands was used to predict turbidity in a glacial lake in Alaska where highly scatter rock flower (Sediment oriented from glacial rock weathering) dominates the particulate fraction and where turbidity varied between 2-997 NTU [17].

The present work is an attempt to understand the inherent variability of turbidity over one of the biggest reservoirs in Gujarat India. No standardized turbidity derived algorithm exists in the scientific community because of the high level of variation in particle size, density and other optical complexities of different water bodies [2009]. As per our knowledge, this is the first attempt to develop an algorithm for assessment of turbidity over Ukai reservoir.

\section{STUDY AREA AND MATERIALS}

\section{A. Study area}

Ukai Reservoir constructed on the river Tapi, is the second largest reservoir in Gujarat, India after Sardarsarovar. The total area of the reservoir is $494.01 \mathrm{~km}^{2}$. The dam is meant for power production, irrigation and flood control. The reservoir also provides water for domestic and industrial use in Surat city and surrounding areas. Average annual rainfall in the catchment is about $900 \mathrm{~mm}$ and mostly concentrated in monsoon months (July and August). In this study, the reservoir area is divided (Figure 1) into three parts, i.e. Down (A), Middle (B) and Up streams $(C)$ for analyzing the variation of water quality parameters.

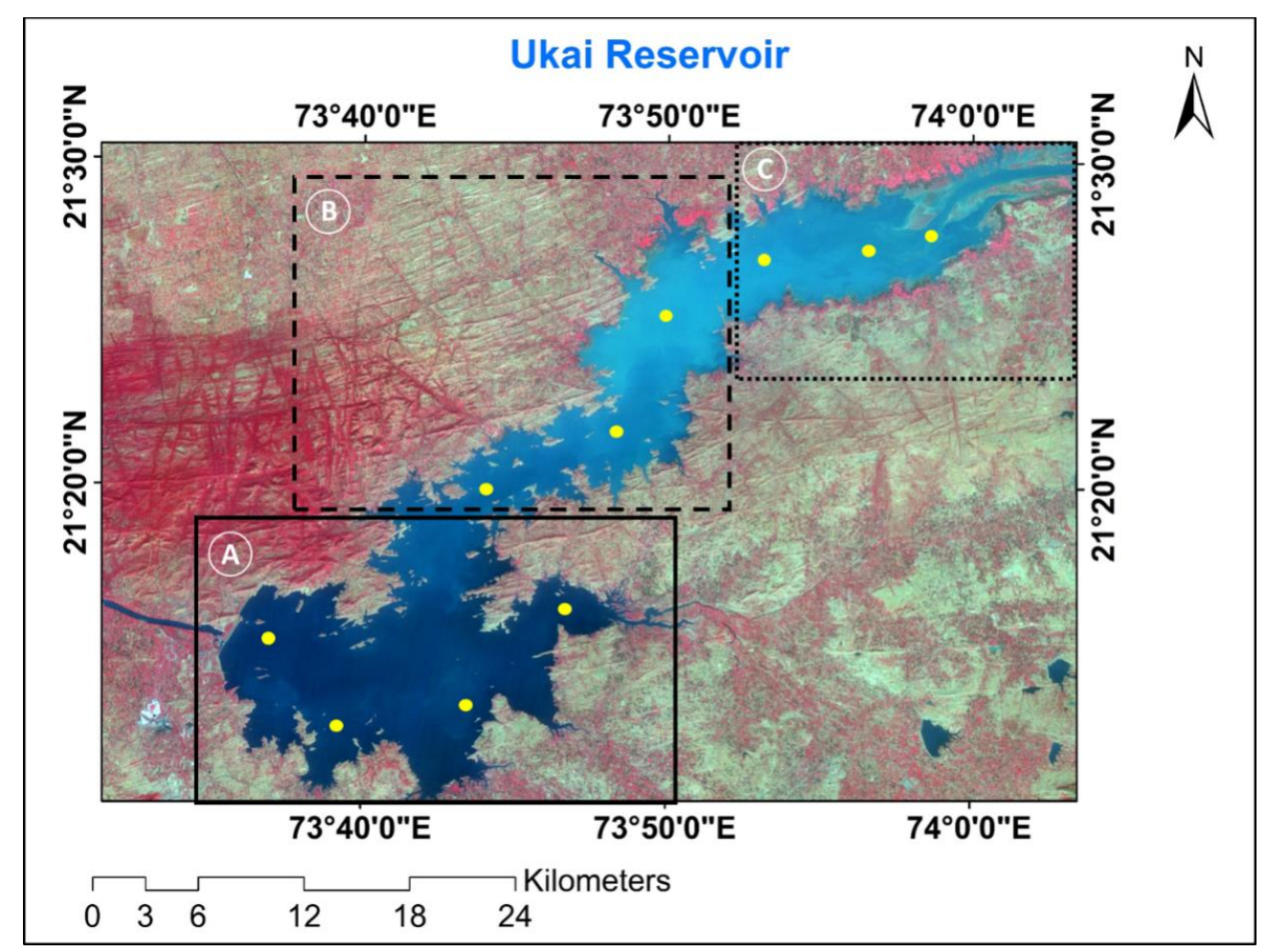

Figure 1 : Study area map of Ukai reservoir in Gujarat, India, with (a) Down, (b) Middle and (c) Up Streams and ROI's which are used to explain spatial variation Figure 5a,5b,5c and 5d. 


\section{B. Satellite data acquisition and field data collection}

Three types of dataset were used, that includes Landsat series of satellite data between 1993 - 2018 in the pre monsoon (March, April and May months) and post monsoon (September, October and November months) seasons, in situ measured remote sensing reflectance (Rrs) and turbidity (NTU: Nephelometric Turbidity Unit) measurements. Landsat images were downloaded from the EarthExplorer (EE) user interface, developed by the United States Geological Survey (USGS), (http://earthexplorer.usgs.gov). The downloaded data includes Landsat 5 Thematic Mapper (TM), Landsat 7 Enhanced Thematic Mapper Plus (ETM+) and Landsat 8 Operational Land Imager (OLI) data from 1993-2018. All selected images were cloud free, the both pre (March, April and May months) and post (September, October and November months) monsoon data sets are taken with similar environmental and hydrological conditions, which represent turbidity variations in pre and post monsoon seasons.

Field measurements were carried out over Ukai reservoir for 27-28 ${ }^{\text {th }}$ March 2018 for pre monsoon and 27-30th September 2018 for post monsoon seasons, sampling sites ranging from turbid to clear water. At every sampling location turbidity was measured with Wetlabs turbidity meter and coordinates were marked using a Global Positioning $\begin{array}{llll}\text { System } & \text { (GPS). An }\end{array}$ FieldSpecspectroradiometerwas used to measure spectral reflectance; it has a spectral range of 350$2500 \mathrm{~nm}$. In accordance with the Ocean Optics protocols [2] [20], the above-water measurement method was used to measure the radiance spectra of the white reference panel, water, and sky respectively. The remote sensing reflectance was derived based on the below equation [28].

$\operatorname{Rrs}(\mathrm{l})=\left(\mathrm{Lt}-\mathrm{r}^{*} \mathrm{Lsky}\right) /\left(\mathrm{Lp}^{*} \pi / \rho \mathrm{p}\right)$

where $\operatorname{Rrs}(\mathrm{l})$ is remote sensing reflectance, $\mathrm{Lt}$ is the measured total radiance of the water surface, $r$ is skylight reflectance at the air-water surface; Lsky is the measured radiance from sky; Lp is the measured of the reference panel; and $\rho p$ is reflectance of the diffuse panel [35].

\section{Satellite data Pre processing}

Landsat images were transformed to top-ofatmosphere radiance (TOA) with the help of radiometric calibration coefficients which are mentioned in the metadata file.There is a variety of atmospheric correction methods and associated models, such as DOS (Dark Object Subtraction), FLAASH (Fast Line of Sight Atmospheric Analysis of Spectral Hypercubes), 6s (Second Simulation of the Satellite Signal in the Solar Spectrum), QUAC (Quick Atmospheric Correction) etc. Among them, FLAASH is one of the widely used and accepted tool because of its higher accuracy and easier use compared to the others [29]. The FLAASH model, which is a MODTRAN-based atmospheric correction software package embedded in ENVI software, is a strong tool for atmospheric correction [37]. Atmospheric correction was done with the FLAASH module, which was incorporated in the Envi (Environment of visualizing images) 5.5 software. The output image was used atmospherically corrected waterbody remote sensing reflectance (Rrs). FLAASH module is considered a good atmospheric correction for terrestrial application [14][21], as well as for an inland water bodies [31]. While using FLAASH module, in put for key parameters used like as, tropical for atmospheric model, rural for the aerosol model and 2 -band (K-T) for the aerosol retrieval and initial visibility was chosen as $40 \mathrm{~km}$.

\section{METHODOLOGY}

The field-collected in situ spectra was converted into simulated bandpass Landsat 8, Landsat 7 and Landsat 5 reflectance using Relative Spectral Response (RSR) function for each channel. To aggregate the reflectance the following equation is used. 


$$
R_{b}=\frac{\sum_{\lambda_{m}}^{\lambda_{n}} R S R_{b}(\lambda) * R(\lambda) d \lambda}{\sum_{\lambda_{m}}^{\lambda_{n}} R S R_{b}(\lambda)}
$$

Where $R_{b}$ denotes simulated aggregate reflectance at band b. $R S R_{b}(\lambda)$ represent Relative Spectral

Response function of band $\mathrm{b}$ within a range from $\lambda_{m}$ to $\lambda_{n}$ channels and $R(\lambda)$ is in situ reflectance spectra. The parametric algorithm based on the combination of bands was tested for estimating the best correlation between water turbidity and simulated Landsat 8, Landsat 7 and Landsat 5 derived reflectance $\left(R_{b}\right)$. Modified Normalized Difference Water Index (MNDWI) [33], was used to mask out the other than water area in images. Among all bands Red band was chosen for the estimation of turbidity in the Ukai reservoir in pre and post monsoon seasons. According to [23] papoutsa et al., 2014, the statistical analysis indicated that a strong correlation between turbidity and reflectance can be obtained for Landsat TM and ETM+, 3 and 4 bands. However, band 4 cannot be used for water reflectance measurements because the water absorption coefficient has a very high value (near to 1) after $800 \mathrm{~nm}$ (approximately), light is mostly absorbed and not reflected by water at wavelength higher than $800 \mathrm{~nm}$. Data corresponding to band 4 are not relevant and are thus not used for the purpose of this study. The very low reflectance values of water at band 4 do not give an opportunity for remote sensing users to retrieve significant aspects of water quality. Empirical methods are based on statistical relationship between remote sensing data and in situ measured water quality data. However, because of the differences among experiment conditions, these statistical relationships are often not stable, as a result, they are difficult to compare and extend from one study to another. In comparison, model-based methods depend on biooptical models and have the advantages of definite physical models and have the robustness and retrieval accuracy[7].

\section{RESULTS AND DISCUSSION}

A number of Turbidity or TSM derived models have been proposed in previous studies. The empirical regression algorithms take advantage of the linear or exponential relations between turbidity and reflectance in certain spectral bands [36] [19] [32]. Till date, there has been no standardized TSMderived model because of the high level of variation in particle size, density and other optical complexities of different water bodies [4]. Because of this reason we need to have a region specific model needed to estimate turbidity in the study region.

Pre monsoon season In situ turbidity ranges 1.47 20 NTU with mean value of 6.13 (standard deviation (S.D.) $=4.76 \mathrm{NTU}$ ) and post monsoon season In situ turbidity ranges $2.44-25$ NTU with mean value of 7.6 (S.D. $=4.76 \mathrm{NTU}$ ).

We used red band to derive turbidity with in situ turbidity measurements and simulated Landsat 5 (TM), Landsat 7 (ETM+) and Landsat 8 (OLI) red band reflectance. Coefficient of Determination $\left(\mathrm{R}^{2}\right)$ was used to evaluate the accuracy of the derived algorithm (Table 1).The correlation analysis showed that there was a significant relation between simulated Landsat 5 (TM), Landsat 7 (ETM+) and Landsat 8 (OLI) red band based derived turbidity and in situ measured turbidity. Coefficient of determination values for pre monsoon season are like this, with Landsat $5(\mathrm{TM}) \mathrm{R}^{2}=0.86$, Landsat 7 $(\mathrm{ETM}+) \mathrm{R}^{2}=0.86$ and Landsat 8 (OLI) $\mathrm{R}^{2}=0.85$ with the in situ turbidity measurements. For the post monsoon season, with Landsat $5(\mathrm{TM}) \mathrm{R}^{2}=0.73$, Landsat $7(\mathrm{ETM}+) \mathrm{R}^{2}=0.73$ and Landsat $8(\mathrm{OLI}) \mathrm{R}^{2}=$ 0.75 with the in situ turbidity measurements. as shown in Fig. 2 left side (A,B and $C$ ) and right side (A,B and $\mathrm{C})$. 
Table 1: Derived algorithms with their correlations coefficients

\begin{tabular}{llll}
\hline \multicolumn{1}{c}{$\mathrm{R}^{2}$} & \multicolumn{2}{c}{ Significance } & \\
\cline { 1 - 2 } Pegression Models & & & \\
Landsat 5: Turbidity (NTU) $=237.14 \mathrm{x}-2.05$ & $\mathrm{R}^{2}=0.86$ & $\mathrm{P}<0.05$ & (3) \\
Landsat 7: Turbidity (NTU) $=236.17 \mathrm{x}-2.06$ & $\mathrm{R}^{2}=0.86$ & $\mathrm{P}<0.05$ \\
Landsat 8: Turbidity (NTU) $=227.48 \mathrm{x}-2.12$ & $\mathrm{R}^{2}=0.85$ & $\mathrm{P}<0.05$ & \\
Post monsoon & & & (5) \\
Landsat 5: Turbidity (NTU) $=131.23 \mathrm{x}+2.46$ & $\mathrm{R}^{2}=0.73$ & $\mathrm{P}<0.05$ \\
Landsat 7: Turbidity (NTU) $=130.89 \mathrm{x}+2.44$ & $\mathrm{R}^{2}=0.72$ & $\mathrm{P}<0.05$ & (7) \\
Landsat 8: Turbidity (NTU) $=126.34 \mathrm{x}+2.30$ & $\mathrm{R}^{2}=0.74$ & $\mathrm{P}<0.05$ & (8)
\end{tabular}

Where $\mathrm{x}$ is red band reflectance.
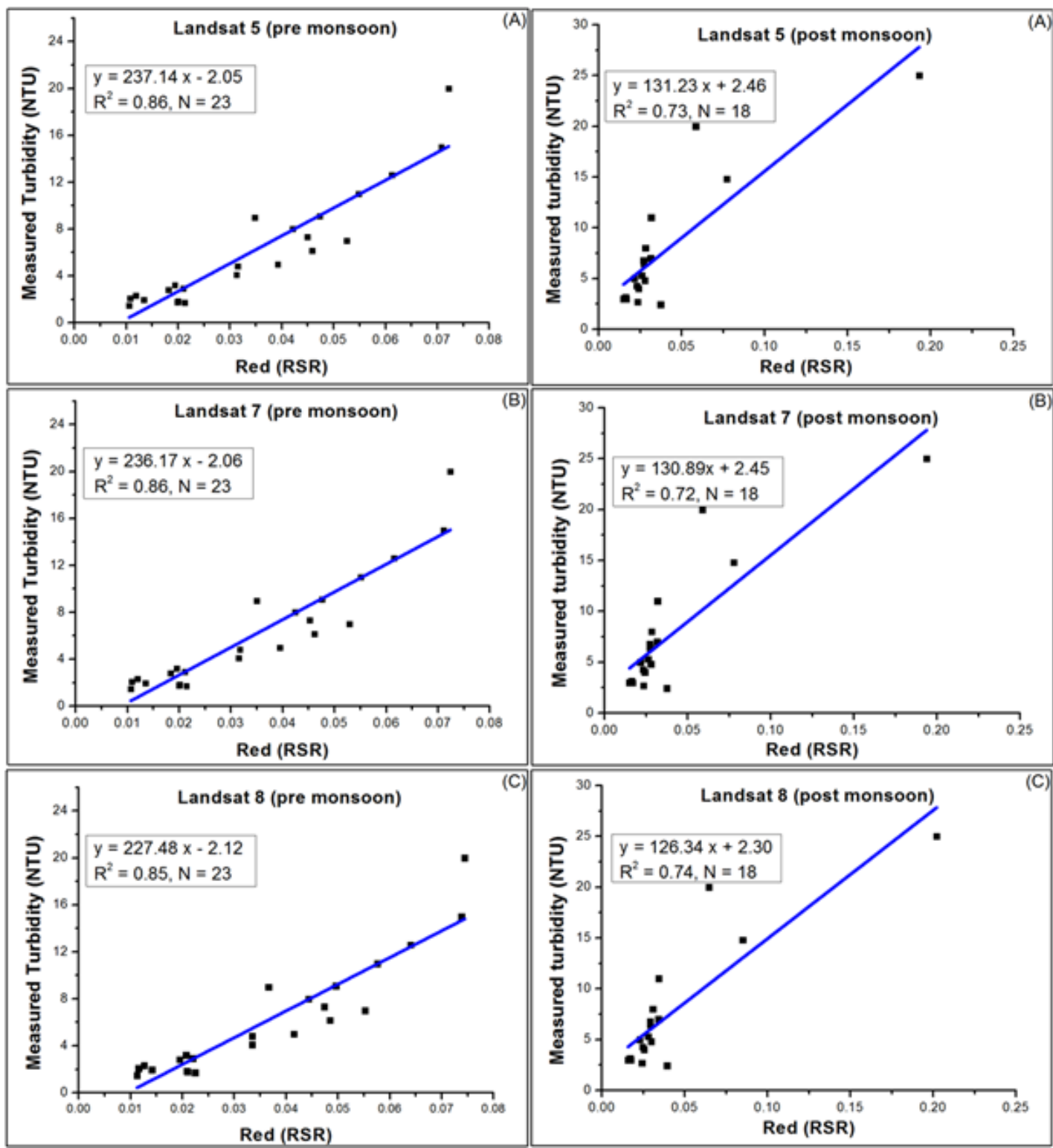

Figure 2: Scatter plots of in situ measured turbidity with derived turbidity using field measured spectra simulated Landsat 5 (TM), Landsat 7 (ETM+) and Landsat 8 (OLI) equivalent bandpass for pre (left side A,B,C) and post (Right side A,B,C) monsoon season. 
Turbidity was derived models (equation 3 to 8 ) were applied to the 52 cloud free Landsat 5 (TM), Landsat $7(\mathrm{ETM}+)$ and Landsat 8 (OLI) images (L5 = 19, $\mathrm{L} 7=21$, and $\mathrm{L} 8=12$ images) from $1993-2018$ for pre and post monsoon seasons. The Landsat derived turbidity pattern results are shown in Figure 3 and 4.

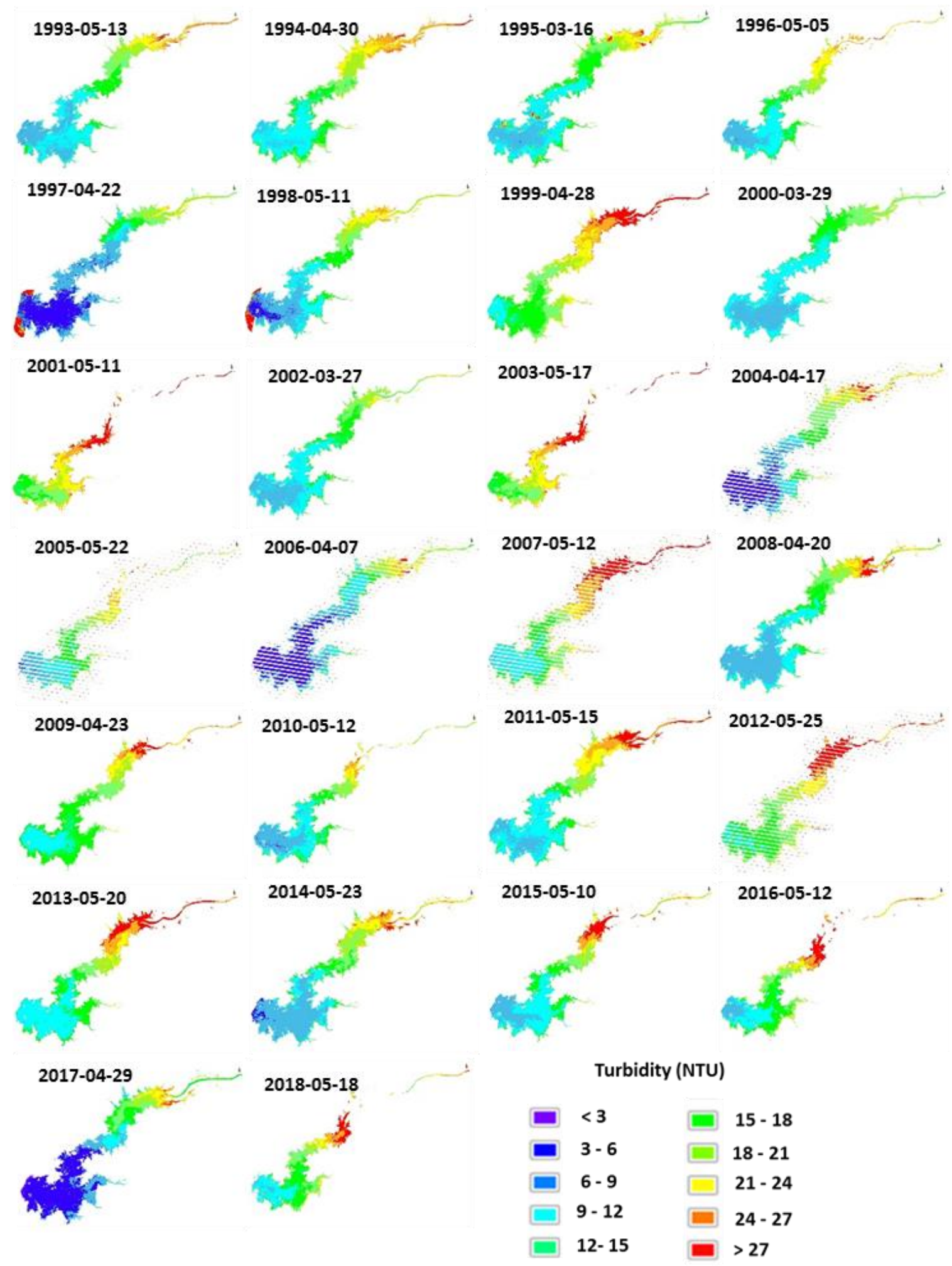

Figure 3: Derived -Turbidity distribution maps in the Ukai Reservoir from 1993 to 2018 for pre monsoon season. 


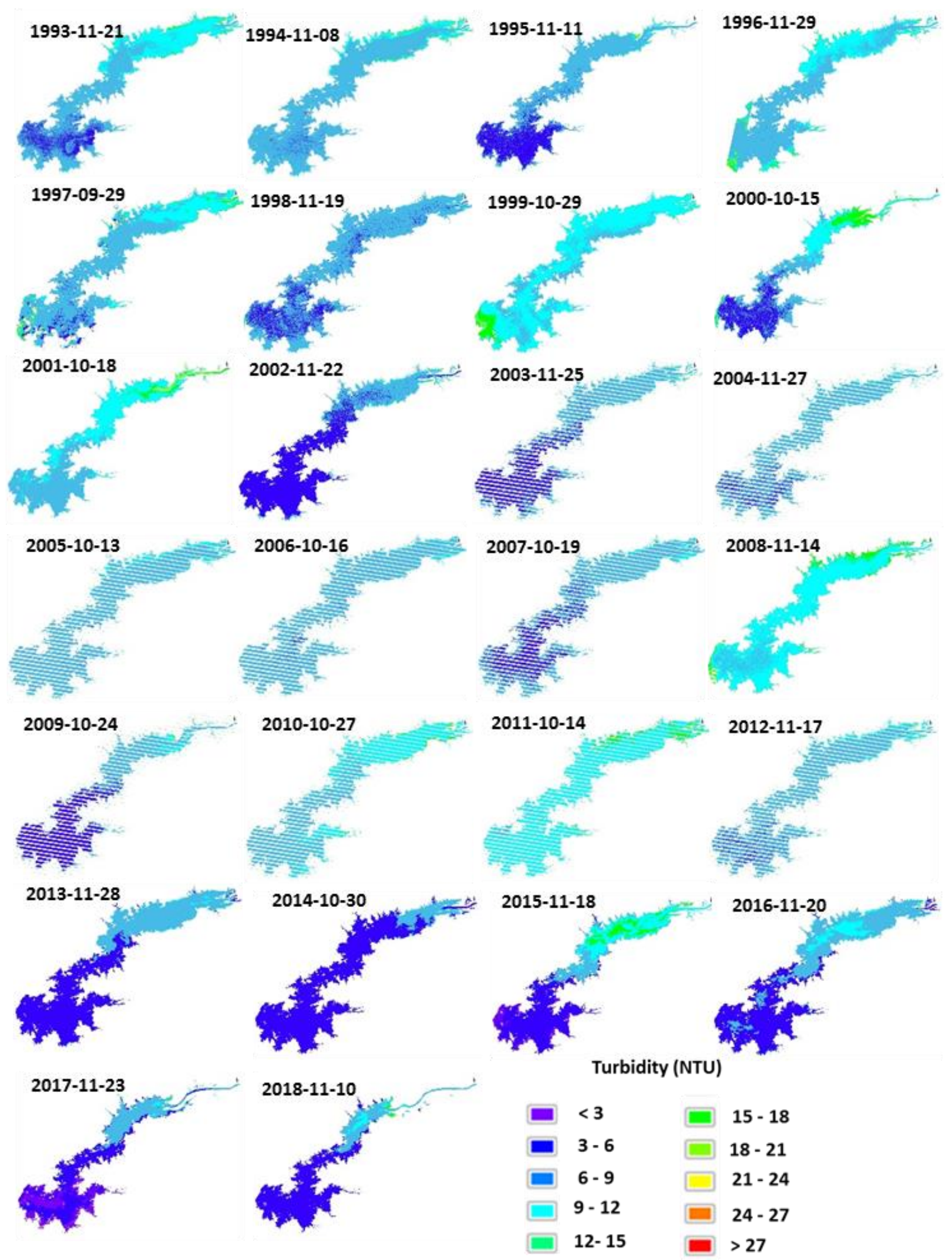

Figure 4 : Derived -Turbidity distribution maps in the Ukai Reservoir from 1993 to 2018 for post monsoon season. 
Most of the existing methods interpreting turbidity propose site-specific empirical relationships between turbidity and reflectance at different satellite wavebands by fitting field turbidity measurements with either field or satellite derived reflectance [8]. Single band or band ratio of two bands is routinely used to develop turbidity as well as other water parameters [22] [27]. In present study Red band was used to estimate turbidity, in pre monsoon case Red band was showing high correlation with in situ turbidity measurements. In the post monsoon case, Green band was showing high correlation with in situ turbidity measurements, Red band showing second highest correlation with in situmeasurements, we ignored the Green band correlation due its atmospheric influencing nature. [12] developed an algorithm for turbidity in the North-western Black sea coastal zone based on the high correlation between the redband of Landsat TM. Lobo et al., 2013 used a time series analysis of Landsat MSS/TM/OLI images to assess the impacts of gold mining activities to Amazonian waters.

This result indicated that water reflectance of the red band of Landsat was the most appropriate for establishing a robust empirical model for TSS or turbidity retrieval [18]. Vanhellemont and Ruddick used Landsat 8 OLI band 4 (i.e Red band) to retrieve turbidity in the southern north sea where the water depth was less than $50 \mathrm{~m}$. In low turbid waters where total suspended solids (TSS) are less than $50 \mathrm{~g} / \mathrm{m}^{3}$, there is high correlation between turbidity and remote sensing reflectance of red region and for high turbidity or TSS exceeding 50 $\mathrm{g} / \mathrm{m}^{3}$, near infrared (NIR) wavelength are recommended for turbidity retrieval[10]. The shift to NIR wavelength for turbidity retrieval is due to the saturation of Rrs in visible wavelengths when TSS concentration exceeds $50 \mathrm{~g} / \mathrm{m}^{3}$, [10] [9]. This study also indicated that NIR wavelength should be used to retrieve suspended sediment matter for the very high turbid waters.In our study, measured turbidity in two field trips were less than 25 NTU, in both pre (23 samples) and post monsoon (18 samples)

seasons. The algorithm that was developed forturbidity retrieval was stable and reliable when using the red band.Figures $5 a, 5 b, 5 c$, and $5 d$ explains estimated pre monsoon season turbidity ranges 3.55 - 32.35 NTU with mean value of 12.84 (standard deviation (S.D.) $=1.66 \mathrm{NTU}$ ) and post monsoon season turbidity ranges $2.72-10.63 \mathrm{NTU}$ with mean value of 6.64 (S.D. = $0.47 \mathrm{NTU}$ ).

In pre monsoon season, reservoir surface area ranges from 137.74 to $337.27 \mathrm{~km}^{2}$, for the same season turbidity ranges from 3.55 to 32.35 NTU. In post monsoon season reservoir surface area ranges from 264.64 to $496.98 \mathrm{~km}^{2}$, for the same season turbidity ranges from 2.72 to 10.63 NTU. Detailed Down, middle and Up stream and surface area and turbidity values are provided in table 2 and 3.In pre monsoon, lowest turbidity value (3.55 NTU) was observed on $7^{\text {th }}$ April 2006 while the highest value (32.35 NTU) was observed on $12^{\text {th }}$ May 2016. The highest value was more than nine times greater than the lowest value, which represents high turbidity variation in Ukai reservoir in the pre monsoon season. In pre monsoon season, lowest surface area $\left(137.74 \mathrm{~km}^{2}\right)$ of the reservoir was observed on $22^{\text {nd }}$ May 2005 and highest surface area $\left(337.27 \mathrm{~km}^{2}\right)$ observed on $16^{\text {th }}$ March 1995 . In post monsoon, lowest turbidity value (2.72 NTU) was observed on $23^{\text {rd }}$ November 2017, highest value (10.63 NTU) was observed on $14^{\text {th }}$ October 2011. The highest value was only 3.9 times more than lowest value, which represents less turbidity variation in Ukai reservoir in post monsoon season and lowest surface area $\left(264.64 \mathrm{~km}^{2}\right)$ of the reservoir was observed on 24 $4^{\text {th }}$ October 2009 and highest surface area $\left(496.98 \mathrm{~km}^{2}\right)$ observed on $19^{\text {th }}$ November 1998. 
V. Pompapathi et al Int J Sci Res Sci \& Technol. November-December-2021, 8 (6) : 236-251

Table 2: Derived turbidity of Ukai reservoir during 1993-2018 categorized into Down, middle and Up stream

\begin{tabular}{|c|c|c|c|c|}
\hline Pre monsoon & Minimum (NTU) & $\begin{array}{c}\text { Maximum } \\
(\mathrm{NTU})\end{array}$ & $\begin{array}{c}\text { Mean } \\
(\mathrm{NTU})\end{array}$ & $\begin{array}{c}\text { Standard } \\
\text { deviation (NTU) }\end{array}$ \\
\hline Down stream & 3.55 & 23.19 & 9.90 & 3.51 \\
\hline Middle stream & 4.72 & 25.34 & 11.43 & 4.13 \\
\hline Up stream & 6.09 & 32.35 & 18.16 & 6.17 \\
\hline Over all Ukai & 3.55 & 32.35 & 12.84 & 5.83 \\
\hline Post monsoon & Minimum & Maximum & Mean & $\begin{array}{c}\text { Standard } \\
\text { deviation }\end{array}$ \\
\hline Down stream & 2.72 & 10.34 & 6.20 & 1.72 \\
\hline Middle stream & 3.19 & 9.77 & 6.47 & 1.54 \\
\hline Up stream & 4.11 & 10.63 & 7.39 & 1.54 \\
\hline Over all Ukai & 2.72 & 10.63 & 6.64 & 1.69 \\
\hline
\end{tabular}

Table 3: Derived turbidity and surface area of Ukai reservoir during 1993-2018 pre and post monsoon season

\begin{tabular}{|c|c|c|c|c|c|c|c|c|c|c|c|}
\hline \multirow{2}{*}{$\begin{array}{l}\text { Pre monsoon data } \\
\text { Acquisition date } \\
\text { (YYYY/MM/DD) }\end{array}$} & \multirow{2}{*}{$\begin{array}{c}\text { Surface } \\
\text { area } \\
\left(\mathrm{km}^{2}\right)\end{array}$} & \multicolumn{4}{|c|}{ Turbidity } & \multirow{2}{*}{$\begin{array}{c}\text { Post monsoon } \\
\text { data } \\
\text { Acquisition date } \\
\text { (YYYY/MM/DD) }\end{array}$} & \multirow{2}{*}{$\begin{array}{l}\text { Surface } \\
\text { area } \\
\left(\mathrm{km}^{2}\right)\end{array}$} & \multicolumn{4}{|c|}{ Turbidity } \\
\hline & & $\begin{array}{c}\text { Minimu } \\
\mathrm{m}\end{array}$ & $\begin{array}{c}\text { Maximu } \\
\mathrm{m}\end{array}$ & \begin{tabular}{c|} 
Mea \\
$\mathrm{n}$
\end{tabular} & S.D & & & $\begin{array}{c}\text { Minimu } \\
\mathrm{m}\end{array}$ & $\begin{array}{c}\text { Maximu } \\
\mathrm{m}\end{array}$ & $\begin{array}{c}\text { Mea } \\
\mathrm{n}\end{array}$ & S.D \\
\hline $1993-05-13$ & 283.10 & 6.92 & 16.01 & 10.70 & 2.75 & 1993-11-21 & 475.98 & 6.04 & 8.48 & 6.85 & 0.73 \\
\hline 1994-04-30 & 300.62 & 9.30 & 19.49 & 12.53 & 3.23 & 1994-11-08 & 473.43 & 6.34 & 7.64 & 6.80 & 0.42 \\
\hline $1995-03-16$ & 337.27 & 8.06 & 13.33 & 9.96 & 1.56 & 1995-11-11 & 365.14 & 5.40 & 6.54 & 5.98 & 0.41 \\
\hline $1996-05-05$ & 208.62 & 7.44 & 21.69 & 13.26 & 4.70 & $1996-11-29$ & 435.67 & 6.73 & 9.13 & 7.36 & 0.71 \\
\hline $1997-04-22$ & 322.48 & 4.96 & 8.60 & 6.25 & 1.09 & 1997-09-29 & 490.99 & 6.38 & 7.83 & 7.04 & 0.47 \\
\hline $1998-05-11$ & 276.68 & 5.89 & 17.75 & 10.51 & 3.64 & 1998-11-19 & 496.98 & 5.87 & 6.41 & 6.09 & 0.17 \\
\hline 1999-04-28 & 287.87 & 10.65 & 23.12 & 16.49 & 3.91 & $1999-10-29$ & 492.42 & 8.30 & 9.95 & 9.34 & 0.43 \\
\hline $2000-03-29$ & 323.04 & 8.02 & 11.58 & 9.64 & 1.19 & $2000-10-15$ & 313.09 & 5.72 & 10.21 & 6.84 & 1.48 \\
\hline 2001-05-11 & 141.17 & 13.08 & 29.28 & 22.66 & 5.35 & 2001-10-18 & 358.12 & 7.75 & 10.57 & 8.73 & 0.76 \\
\hline $2002-03-27$ & 253.05 & 7.91 & 14.17 & 10.51 & 1.85 & 2002-11-12 & 414.45 & 4.42 & 5.74 & 5.04 & 0.39 \\
\hline 2003-05-17 & 238.44 & 13.99 & 26.17 & 19.05 & 4.06 & 2003-11-25 & 327.20 & 5.51 & 6.66 & 5.84 & 0.33 \\
\hline 2004-04-17 & 233.42 & 4.27 & 16.70 & 8.93 & 4.23 & 2004-11-27 & 277.50 & 5.95 & 7.53 & 6.56 & 0.54 \\
\hline $2005-05-22$ & 137.74 & 6.97 & 23.56 & 14.76 & 5.35 & $2005-10-13$ & 376.35 & 6.64 & 7.32 & 6.88 & 0.21 \\
\hline 2006-04-07 & 238.37 & 3.55 & 9.19 & 5.80 & 1.65 & $2006-10-16$ & 372.64 & 6.60 & 7.18 & 6.89 & 0.20 \\
\hline $2007-05-12$ & 211.74 & 9.55 & 24.29 & 15.78 & 5.59 & 2007-10-19 & 378.62 & 5.77 & 6.30 & 6.02 & 0.17 \\
\hline 2008-04-20 & 321.56 & 7.53 & 13.73 & 9.49 & 1.95 & 2008-11-14 & 431.15 & 8.96 & 10.21 & 9.40 & 0.38 \\
\hline $2009-04-23$ & 249.55 & 10.97 & 20.39 & 14.24 & 2.92 & $2009-10-24$ & 264.64 & 4.96 & 6.77 & 5.69 & 0.49 \\
\hline $2010-05-12$ & 195.79 & 7.53 & 23.81 & 13.03 & 5.16 & $2010-10-27$ & 340.00 & 8.12 & 9.04 & 8.43 & 0.31 \\
\hline 2011-05-15 & 303.98 & 8.65 & 21.97 & 12.61 & 4.64 & 2011-10-14 & 360.55 & 9.41 & 10.63 & 10.04 & 0.40 \\
\hline $2012-05-25$ & 202.97 & 11.96 & 27.00 & 17.36 & 4.94 & 2012-11-17 & 345.53 & 6.25 & 7.28 & 6.74 & 0.40 \\
\hline 2013-05-20 & 274.51 & 10.02 & 24.61 & 14.61 & 4.82 & 2013-11-28 & 481.95 & 3.95 & 6.09 & 4.69 & 0.67 \\
\hline 2014-05-23 & 298.32 & 6.28 & 17.82 & 10.45 & 4.00 & $2014-10-30$ & 440.29 & 3.90 & 5.06 & 4.21 & 0.33 \\
\hline $2015-05-10$ & 238.29 & 7.85 & 23.11 & 13.14 & 4.73 & $2015-11-18$ & 394.13 & 3.01 & 9.66 & 5.36 & 2.16 \\
\hline 2016-05-12 & 189.75 & 8.28 & 32.35 & 17.33 & 7.70 & 2016-11-20 & 468.03 & 4.75 & 8.47 & 6.12 & 1.08 \\
\hline 2017-04-29 & 321.21 & 4.13 & 14.28 & 7.08 & 3.07 & $2017-11-23$ & 321.60 & 2.72 & 7.62 & 4.45 & 1.39 \\
\hline 2018-05-18 & 165.35 & 9.57 & 27.99 & 17.61 & 6.65 & 2018-11-10 & 284.39 & 3.93 & 8.09 & 5.19 & 1.16 \\
\hline
\end{tabular}

International Journal of Scientific Research in Science and Technology (www.ijsrst.com) | Volume 8 | Issue 6 


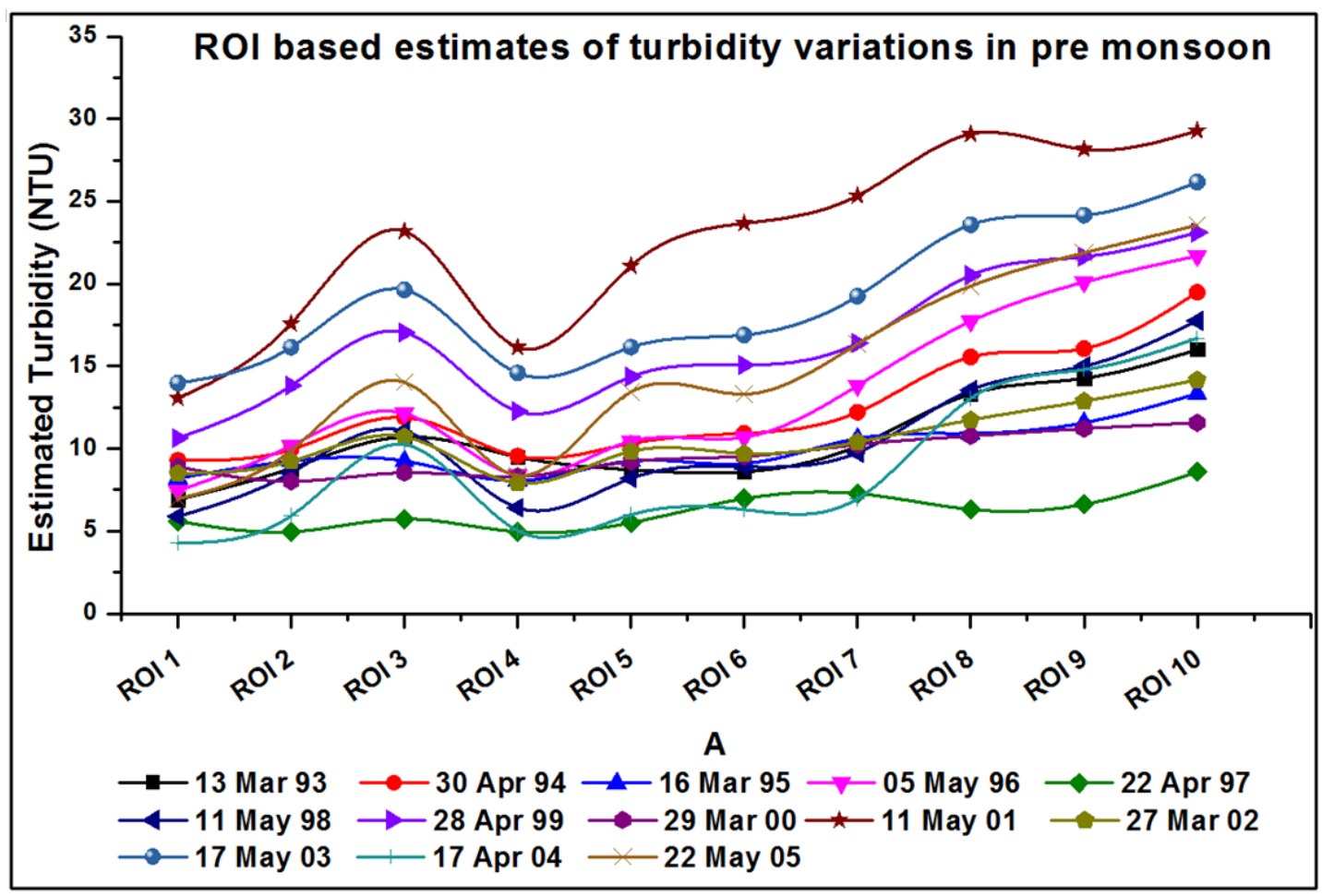

Figure 5a : Derived -Turbidity variations in the Ukai Reservoir from 1993 to 2005 for pre monsoon season.

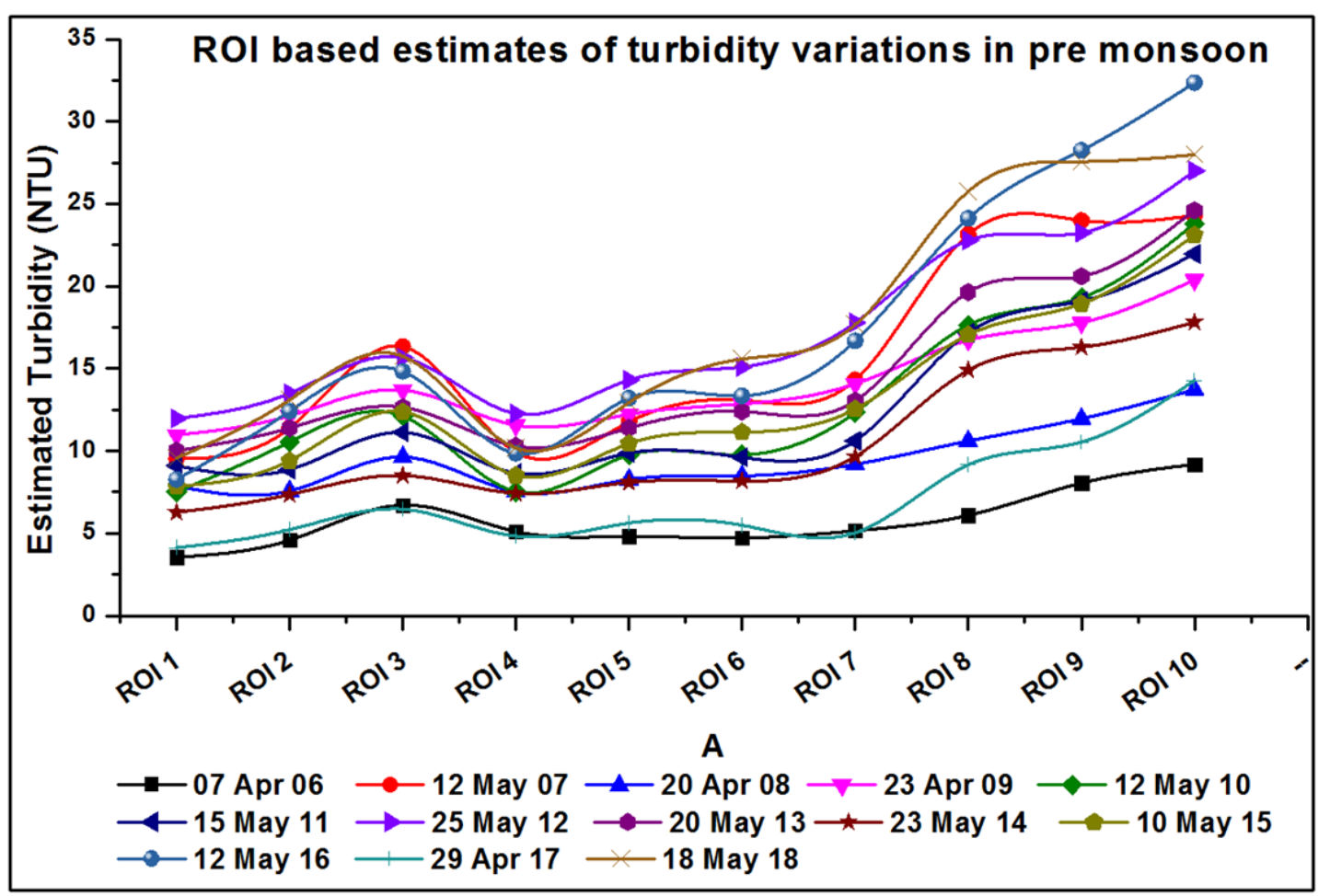

Figure 5b: Derived -Turbidity variations in the Ukai Reservoir from 2006 to 2018 for pre monsoon season. 


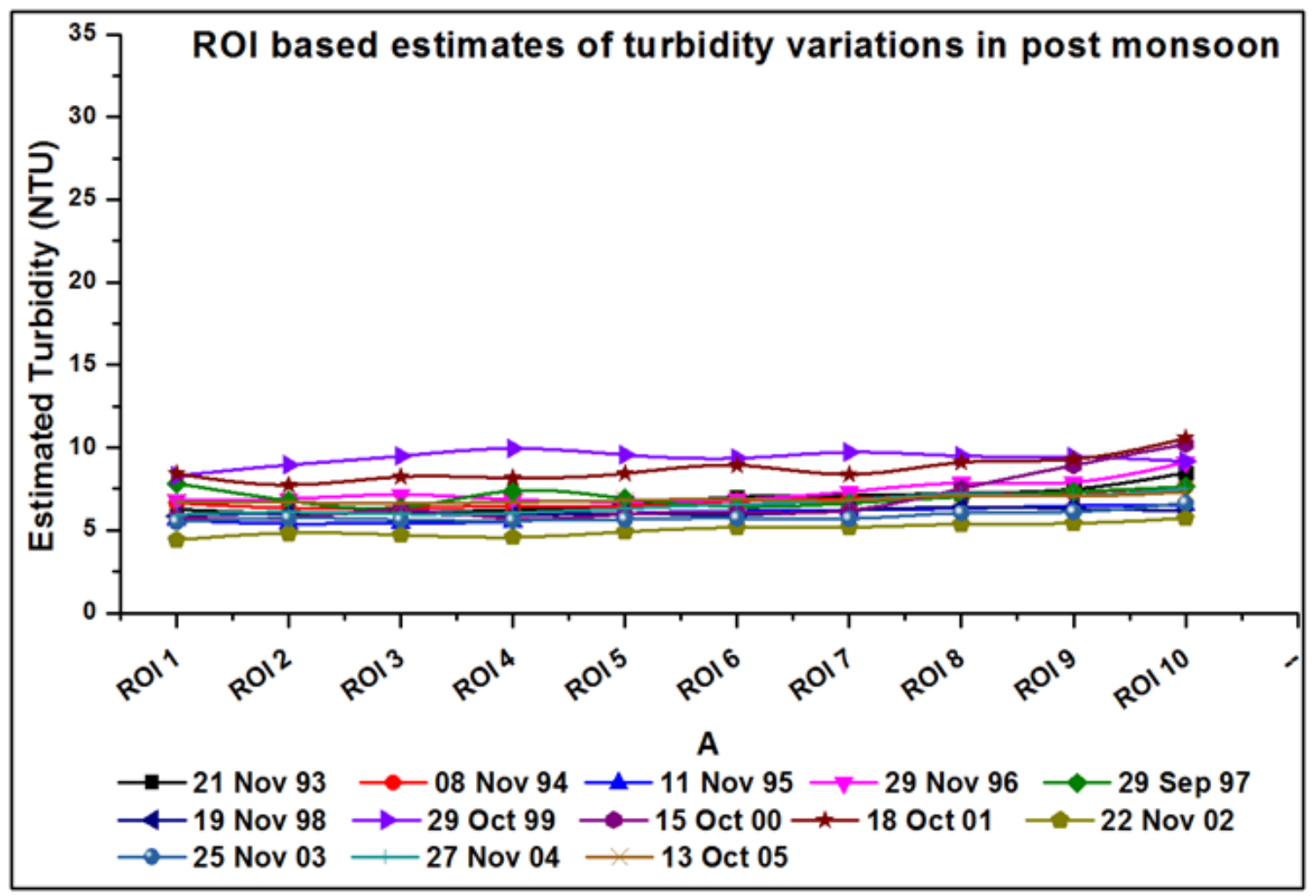

Figure 5c:Derived -Turbidity variations in the Ukai Reservoir from 1993 to 2005 for post monsoon season.

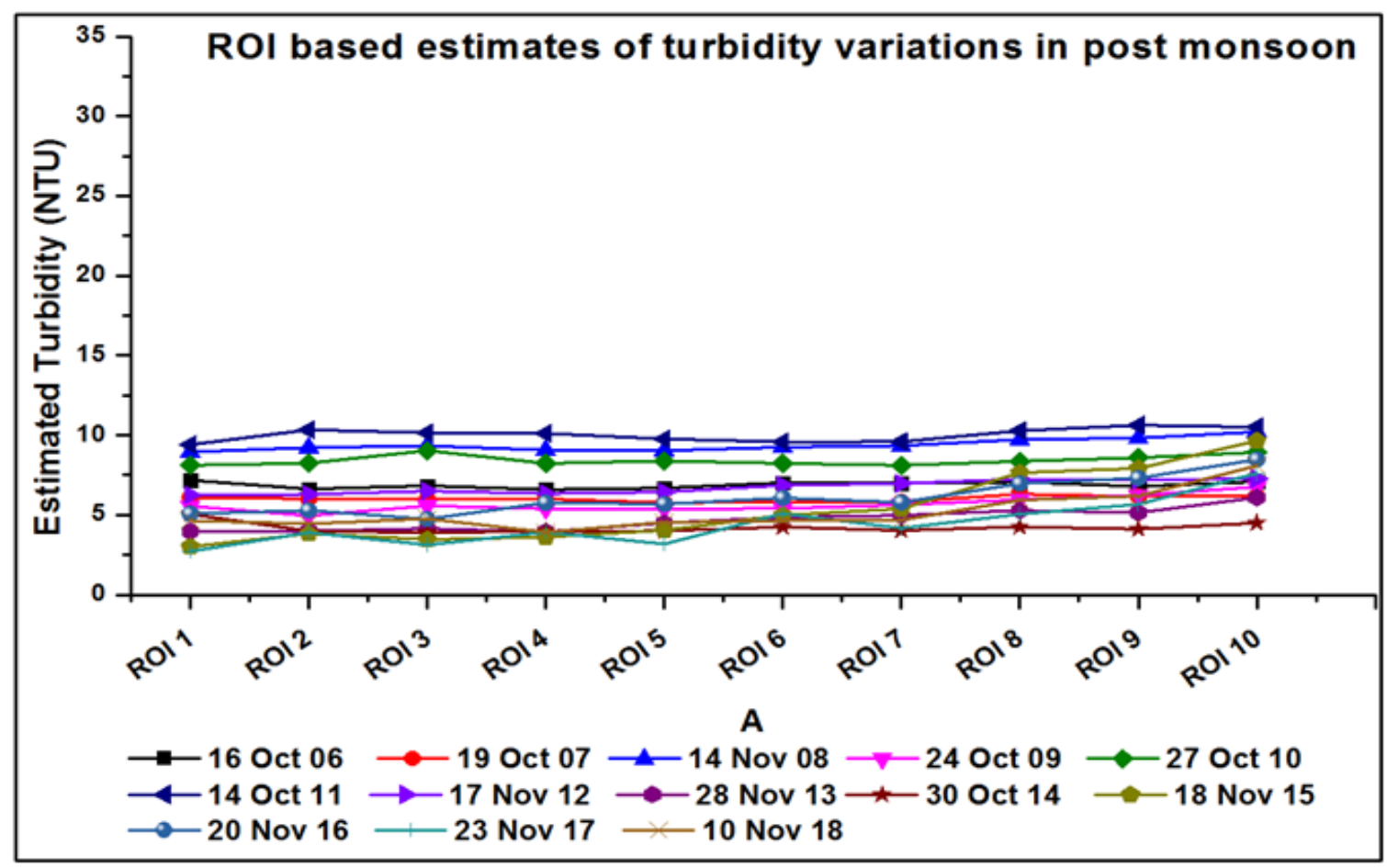

Figure 5d:Derived -Turbidity variations in the Ukai Reservoir from 2006 to 2018 for the post monsoon season. 


\section{v. CONCLUSION}

Estimated Pre monsoon turbidity ranges were 3.55 -32.35 NTU, the lowest value is more than 9 times to highest value. In the post monsoon turbidity range was 2.72-10.63 NTU the lowest value is just 3 times to highest value. This represents, in the pre monsoon turbidity variations was more than the post monsoon turbidity variations. Derived algorithm shows a strong coefficient of determination $\mathrm{R}^{2}=0.86-0.85,0.75-0.72$ with the in situ turbidity measurements in pre and post monsoon seasons respectively. Less than 30-40 NTU turbidity is able to derive with help of Red band, more than the 40 NTU turbidity water spectral signature shifts towards NIR band region. In both pre and post monsoon, down- stream was having less turbidity variation and Up- stream had high turbidity variations.

The Study provides (1) Sensor specific, Red band based algorithm for assessment of turbidity over Ukai reservoir during 1993 - 2018 (26 years) pre and post monsoon seasons. (2) An empirical method that applied a thorough analysis to derive turbidity variation Among Landsat 5 (TM), Landsat 7 (ETM+) and Landsat 8 (OLI) Satellites. Some uncertainties remain with the empirical algorithm, in the future study should be conducted to incorporate factors such as particle size, shape, colour and mineral type as well as organic substance and chlorophyll that may affect the optical properties of turbid waters. Results obtained through this study could serve as a basic foundation for the assessment of turbidity and remaining water quality parameters in Ukai reservoir, and it also be used in various numerical models to help characterize the tropic state of an inland aquatic ecosystem.

\section{ACKNOWLEDGMENT}

The authors are thankful to Shri.Nilesh M Desai, Director, Space Applications Centre (SAC), Indian
Space Research Organisation (ISRO) and Dr.Ish Mohan Bahuguna, Deputy Director, Earth, Ocean, Atmosphere and Planetary Sciences and Applications Area (EPSA), SAC, for their overall support. The work was carried out under GISAT: Science and Application Project. Authors are also thankful to Executive Engineer Ukai Division No 1, Ukai and District Forest Officer Vyara, District Tapi for helping in carrying out the water quality measurements over Ukai reservoir.

\section{VII.REFERENCE}

[1]. Allan, M. G., Hamilton, D. P., Hicks, B. J., \&Brabyn, L. (2011). Landsat remote sensing of chlorophyll a concentrations in central North Island lakes of New Zealand. International Journal of Remote Sensing, 32, 2037-2055.

[2]. Analytical Spectral Devices, Inc. (ASD). (2006). FieldSpec 3 User Manual.

[3]. Bastamante, J., Pacios, F., Diaz-Delgado, R., \& Aragonés, D. (2009). Predictive models of turbidity and water depth in the Doñana marshes using LANDSAT TM and ETM+ images. Journal of Environment management, 90, 2219-2225.

[4]. Bowers, D. G., Braithwaite, K. M., NimmoSmith, W. M., \& Graham, G. W. (2009). Light scattering by particles suspended in the sea: The role of particle size and density. Continental shelf Research, 29, 1748-1755.

[5]. Chen, X., Yan, Y., Fu, R., Dou, X., \& Zhang, E. (2008). Sediment transport from the Yangtze River, China, into the sea over the Post-Three Gorge Dam Period: A discussion. Quaternary International - QUATERN INT. 186, 55-64.

[6]. Choubey, V. K. (1992). Correlation of tubidity with indian Remote Sensing Satellite-1A data. Hydrological Sciences, 37(2), 129-140.

[7]. Dekker, A. G., Vos, R. J., \& Peters, S. M. (2002). Analytical algorithms for lake water 
TSM estimation for retrospective analyses of $\mathrm{TM}$ and SPOT sensor data. International Journal of Remote Sensing, 23, 15-35.

[8]. Dogliotti, A. I., Ruddick, K. G., Nechad, B., Doxaran, D., \&Knaeps, E. A. (2015). A single algorithm to retrieve turbidity from remotely-sensed data in all coastal and esturine waters. Remote Sensing of Environment, 156, 157-168.

[9]. Fang, S., Suhyb, S. H., Zhou, Y. X., Li, J. F., $\mathrm{Su}, \mathrm{Z}$., \&Kuang, D. B. (2010). Remote-sensing reflectance characteristics of highly turbid esturine waters- A comparative experiment of the Yangtze River and the Yellow River. International journal of Remote Sensing, 31, 2639-2654.

[10]. Gernez, P., Barille, L., Lerouxel, A., Mazeran, C., Lucas, A., \&Doxaran, D. (2014). Remote sensing of suspended particulate matter in turbid oyster-farming ecosystems. Journal of Geophysical Research: Oceans, 119, 72777294.

[11]. Goodin, D. G., Harrington, J. A., Jr, Druane Nellis, M., \& Rundquist, D. C. (1996). Mapping reservoir turbidity patterns using SPOT-HRV data. Geocarto International, 11 (4), 71-78.

[12]. Guttler, F. N., Niculescu, S., \&Gohin, F. (2013). Turbidity retrieval and monitoring of Danube Delta waters using multisensor optical remote sensing data: An integrated view from the delta plain lakes to the western-northwestern Black Sea coastal zone. Remote Sensing of Environment, 132, 86-101.

[13]. Hu, C., Chen , Z., Clayton, T. D., Swarzenski, P., Brock, J. C., \& Muller-karger, F. E. (2004). Assessment of esturine water-quality indicators using MODIS medium-resolution bands: Initial results from Tampa bay, Florida. Remote Sensing of Environment, 93, 423-441.

[14]. Kaufman, Y. J., Tanre, D., Remer, L. A., Vermote, E. F., Chu, A., \&Holben, B. N.
(1997). Operational remote sensing of tropospheric aerosol over land from EOS Moderate Resolution Imaging Spectroradiometer. Journal of Geophysical research, 102, 17051-17067.

[15]. Kishino, M., Tanaka, A.,\& Ishizaka, J. (2005). Retrieval of Chlorophyll a, suspended solids, and colored dissolved organic matter in Tokyo Bay using ASTER data. Remote Senisng of Environment, 99, 66-74.

[16]. Kloiber, S. M., Brezonik, P. L., Olmanson, L. G., \& Bauer, M. E. (2002). A procedure for regional lake water clarity assessment using Landsat multispectral data. Remote Sensing of Environment, 82, 38-47.

[17]. Liversedge, L. (2007). Turbidity mapping and prediction in ice marginal lakes at the Bering Glacier System, Alaska. (M.S. thesis). University of Michigan, School of natural Resources and Environment, (50 pp.).

[18]. Lobo, F. L., Costa,M., P. F., \&Novo,E.M., L. M. (2013). Time-series analysis of LandsatMSS/TM/OLI images over Amazonian waters impacted by gold mining activities. Remote Sensing of Environment, 157, 170-184.

[19]. Ma, R. H., \& Dai, J. F. (2005). Investigation of chlorophyll-a and total suspended matter concentrations using Landsat ETM and field spectral measurement in Taihu Lake, China. International Journal of Remote sensing, 26, 2779-2795.

[20]. Morel, A., \& Mueller, J. L. (n.d.). Normalized water-leaving radiance and remote sensing reflectance: Bidirectional reflectance and other factors. . Retrieved from Available online:http://ntrs.nasa.gov/archive/nasa/casi.n trs.nasa.gov/20020044099.pdf accessed 26 Dec 2018.

[21]. Nazeer, M., Nichol, J. E., \& Yung, Y. K. (2014). Evaluation of atmospheric correction models and Landsat surface reflectance product in an urban coastal environment. 
International Journal of Remote Sensing, 35, 6271-6291.

[22]. Ouillon, S., Douillet, P., \&Andrefouet, S. (2004). Coupling satellite data with in situ measurements and numerical modeling to study fine suspended-sedimnettraasport: A study for the lagoon of new Caledonia. Coral Reefs, 23, 109-122.

[23]. Papoutsa, C., Retalis, A., Toulios, L., \&Hadjimitsis, D. G. (2014). Defining the Landsat TM/ETM+ and chris/proba spectral regions in which turbidity can be retrived in inland waterbodies using field spectroscopy. International Journal of Remote Sensing, 35(5), 1674-1692.

[24]. Petus, C., Chust, G., Gohin, F., Doxaran, D., Froidefond, J. -M., \& Sagarminaga, Y. (2010). Estimating turbidity and total suspended matter in the Adour River plume (South Bay of Biscay) Using MODIS 250-m imagery. Continental Shelf Research, 30, 379-392.

[25]. Pozdnyakov, D., Shuchman, R., Korosov, A., \&Hatt, C. (2005). Operational algorithm for the retrival of water quality in the great lakes. Remote Snesing of Environment, 97(3), 352370.

[26]. Qi, F., \&Wang, X. J. (1999). Application of remote sensing techniques in montoring and assessing inland water quality. Advances in Environmental Science, 7(3), 90-99.

[27]. Ritchie, J. C., Zimba, P. V., \&Everitt, J. H. (2003). Remote Sensing techniques to assess water quality. Photogrammetric Engineering and Remote Sensing, 69, 695-704.

[28]. Tang, J. W., Tian, G. L., Wang, X. Y., Wang, X. M., \& Song, Q. J. (2004). The methods of water spectra measurement and analysis I: Above-water method. J.Remote Sens. Beijing, 8,37-44.

[29]. Tebbs, E. J., Remedios, J. J., \& Harper, D. M. (2013). Remote sensing of chlorophyll-a as a measure of cyanobacterial biomass in Lake
Bogoria, a hypertrophic, saline-alkaline, flamingo lake, using Landsat ETM+. Remote Sensing of Environment, 135, 92-106.

[30]. Vanhellemont, Q., \& Ruddick, K. (2014). Turbid wakes associated with offshore wind turbines observed with Landsat 8. Remote Sening of Environment, 145, 105-115.

[31]. Wang, Y., Li, Y., Lv, H., Wu, C., Jin, X., Yin, B., \& Zhang, H. (2011). Suitability assessment of lake water quality monitoring on waterbody images acquired by $\mathrm{HJ}-1 \mathrm{~A}$ hyperspectral imager: A case study of Lake Chaohu. Journal of Lake Sciences, 23, 789795.

[32]. Wu, G. F., Cui, L. J., Liu, L. J., Chen, F. Y., Fei, T., \& Liu, Y. L. (2015). Statistical model development and estimation of suspended particulate matter concentrations with Landsat 8 OLI images of Dongting Lake, China. International Journal of Remote Sensing, 36, 343-360.

[33]. Xu, H. (2006). Modification of normalised difference water index (NDWI) to enhance open water features in remotely sensed imagery. International Journal of Remote Sensing, 3025-3033.

[34]. Zhang , Y. L., Qin, B. Q., Chen, W. M., \& Luo, L. C. (2004). A Study on total suspended matter in lake taihu. Resources and Environment in the Yangtze Basin, 13(3), 266-271.

[35]. Zheng, Z., Li, Y., Guo, Y., Xu, Y., Liu, G., \& $\mathrm{Du}, \quad$ C. (2015). Lastsat-Based Long-Term Monitoring of Total Suspended Matter Concentration Pattern Change in the Wet Season for Dongting Lake, China. Remote Sens, 13975-13999.

[36]. Zhou, W., Wang, S., Zhou, Y., \& Troy, A. (2006). Mapping the concentrations of total suspended matter in Lake Taihu, China, using Landsat-5TM data. International Journal of Remote Sensing, 27, 1177-1191. 
[37]. Zhubin, Z., Yunmei, L., Yulong, G., Yifan, X., Ge, L., \&Chenggong, D. (2015). Landsat-based long-term monitoring of total suspended matter concentration pattern change in the wet season for Dongting Lake, China. Remote sensing, 7, 13975-13999.

\section{Cite this article as :}

V. Pompapathi, Shard Chander, Ashwin Gujrati, H.A. Solanki, R. P. Singh, "Monitoring of Turbidity Variation in the Ukai Reservoir, Gujarat, INDIA, during 1993-2018 using Landsat Series of Dataset", International Journal of Scientific Research in Science and Technology (IJSRST), Online ISSN : 2395-602X, Print ISSN : 2395-6011, Volume 8 Issue 6, pp. 236-251, November-December 2021. Available at doi : https://doi.org/10.32628/IJSRST218620 Journal URL : https://ijsrst.com/IJSRST218620 